\title{
SUSTAINABLE DEVELOPMENT GOALS INTEGRATED IN PROJECT- BASED LEARNING IN THE MECHANICAL ENGINEERING DEGREE
}

\author{
Modesto Pérez-Sánchez ${ }^{1}$, Raquel Sanchis ${ }^{2}$ \\ ${ }^{1}$ Dpto. de Ingeniería Hidráulica y Medio Ambiente, Escuela Politécnica Superior de Alcoy. \\ Universitat Politècnica de València (SPAIN) \\ ${ }^{2}$ Dpto. de Organización de Empresas, Escuela Politécnica Superior de Alcoy. Universitat \\ Politècnica de València (SPAIN)
}

\begin{abstract}
The Sustainable Development Goals (SDGs) are an action plan to reach a better and more sustainable future for everybody. This is the main reason why universities have to make a special effort to instil in students the importance of the SDGs as well as promote actions addressed to the end poverty, the protection of the planet and the improvement of lives and prospects of everyone in any place. In light of this, one of the methodologies that currently is very used by universities is ProjectBased Learning (PBL). This methodology promotes active teaching in which students are the main actors. With this methodology students solve challenging situations, raise questions, and try to answer them using their knowledge, means, resources, research, reflection in an active and collaborative way. It is not a new methodology, but it is unquestionable that in the last years it has been implemented in a generalized way in comparison with other educational trends. The objective of this paper is to define a learning approach based on PBL to achieve and enhance students' knowledge about SDGs. In addition, the paper also shows an illustrative example of a PBL model applied to some of the 17 SGDs that can be the basis for other teachers to apply the PBL methodology to develop students' capacity to achieve SGDs in other subjects and/or degrees.
\end{abstract}

Keywords: Sustainable Development Goals, Project-Based Learning, Active Methodology, Mechanical Engineering Degree.

\section{INTRODUCTION}

Current society increasingly demands that future professionals are sustainable to promote prosperity while protecting the planet. In the same way, more and more companies require competent professionals specialized in a specific knowledge domain but who also possess soft skills. Due to the importance of transversal competences in the professional performance of students, universities have explicitly incorporated in their degrees and postgraduate degrees, these competences to [1]:

- Provide students with an added value that can differentiate them from other students.

- Make the studies offered by a specific university more attractive compared to similar ones from other universities.

- To value the training of students in the face of employers.

- Make the acquisition of competences explicit for international accreditations.

To achieve these objectives, active methodologies are required, such as project-based learning (PBL). The PBL methodology is based on the fact that each student develops their own knowledge in a transversal way in all the subjects that participate in the project. Therefore, the objective of this paper is to define a learning approach based on PBL to achieve and enhance students' knowledge about SDGs in parallel with the TCs. In addition, the paper also shows an illustrative example of a PBL model applied to some of the 17 sustainable development goals (SGDs) that can be the basis for other teachers to apply the PBL methodology to develop students' capacity to achieve SGDs in other subjects and/or degrees.

The paper is structured as follows. Section 2 provides a general overview of the main concepts of this contribution. An overview of the transversal competences and the sustainable development goals is performed together with the description of the active PBL methodology. Section 3 describes a case study with the design of the PBL application to work on the SGDs and transversal competences (TCs) in the Mechanical Engineering Degree. Finally, section 4 describes the main conclusions of this work. 


\section{BACKGROUND}

\subsection{Transversal Competences (TCs)}

From a labour market applicability viewpoint, there are two types of competences [2]:

- General or transversal competences required in any type of work or professional context.

- Specific or technical competences that are addressed to particular specialised environment.

This contribution is focused on the first one. Transversal competences are generic and relevant skills that students have to develop through the several stages of the educational degrees [3].

The relevance of the attainment of transversal competences (TCs) in Higher Education is, of course, addressed to the students' future profession but also for the accreditation of study programs and higher education institutions (HEls) [4].

\subsubsection{TCs Project in Universitat Politècnica de València (UPV)}

UPV has designed and implemented a TCs project to provide students with the necessary knowledge and skills to solve problems in new or unfamiliar environment within broader (or multidisciplinary) contexts related to an area of study. This project differentiates three lines to incorporate 13 TCs to studies [5]:

- Through the study plans: By including the TCs in the verification reports; the assignment of TCs to the different subjects that make up the study plan; the definition of TCs in the teaching guide of the subjects; and by monitoring and reviewing that the incorporation of the TCs into the study plans is being carried out correctly.

- Through the end-of-degree and master's projects: These projects offer a particularly suitable learning scenario to continue developing TCs, since they imply to put into action a vast amount of the knowledge acquired by students, facilitating, in this way, its integration and transfer.

- Through extracurricular activities: TCs are learned over long periods of time and in very different contexts, both academic and extra-academic. This project also contemplates the learning that students can incorporate from other contexts.

The TCs UPV project seeks to synthesize a competences' profile that all UPV graduates acquire, guaranteeing that the reference framework of all degrees is covered. Thirteen generic or transversal competences (TC) were defined and introduced within all the curricula: Understanding and integration (TC-1), Application practical thinking (TC-2), Analysis and problem solving (TC-3), Innovation, creativity and entrepreneurship (TC-4), Project design (TC-5), Teamwork and leadership (TC-6), Professional and ethical responsibility (TC-7), Effective communication (TC-8), Critical thinking (TC-9), Knowledge of contemporary issues (TC-10), Continuous learning (TC-11), Planning and time management (TC-12), and Instrumental specific (TC-13) [6].

Finally, and with regards to the TCs evaluation, the project [7] seeks to define evaluative strategies that focus on the performance of educational activities performed by the students. These activities should be as authentic as possible and should be designed with an appropriate level of complexity according to the learning moment when it is performed and the context in which the learning process takes place.

At the beginning, such evaluation strategies can be more informal as feedback (immediate, frequent and formative) is essential to provide students with valuable information about their knowledge acquisition level. As the learning process progresses, it is vital to evolve towards more integrative tasks in which students test their ability to mobilize the different components of one or more competences in increasingly complex situations.

\subsection{Sustainable Development Goals (SDGs)}

The Sustainable Development Goals (SDGs) proposed by Union Nations were defined in Rio+20 Conference. These SDGs are 17 (Table 1), and they define 169 different goals that countries have to reach in 2030 [8]. The objective of these SDGs is "to promote prosperity while protecting the planet. They recognize that ending poverty must go hand-in-hand with strategies that build economic growth and address a range of social needs including education, health, social protection, and job opportunities, while tackling climate change and environmental protection" [9]. 
Table 1. SDGs Objectives.

\begin{tabular}{|c|c|}
\hline Goals & Definition \\
\hline Goal 1: End poverty & To end poverty in all its forms everywhere by 2030 . \\
\hline Goal 2: Zero Hunger & $\begin{array}{l}\text { To end hunger, achieve food security and improved nutrition and promote } \\
\text { sustainable agriculture. }\end{array}$ \\
\hline Goal 3: Good health and well-being & To ensure healthy lives and promote well-being for all at all ages. \\
\hline Goal 4: Quality Education & Ensure inclusive and quality education for all and promote lifelong learning. \\
\hline Goal 5: Gender Equality & To achieve gender equality and empower all women and girls. \\
\hline Goal 6: Clean Water and Sanitation & To ensure access to safe water sources and sanitation for all. \\
\hline Goal 7: Affordable and Clean Energy & $\begin{array}{l}\text { To ensure access to affordable, reliable, sustainable and modern energy } \\
\text { for all. }\end{array}$ \\
\hline $\begin{array}{l}\text { Goal 8: Decent Work and Economic } \\
\text { Growth }\end{array}$ & $\begin{array}{l}\text { To promote inclusive and sustainable economic growth, employment and } \\
\text { decent work for all. }\end{array}$ \\
\hline $\begin{array}{l}\text { Goal 9: Industries, Innovation and } \\
\text { Infrastructure }\end{array}$ & $\begin{array}{l}\text { To build resilient infrastructure, promote inclusive and sustainable } \\
\text { industrialization and foster innovation. }\end{array}$ \\
\hline Goal 10: Reduced Inequalities & To reduce inequalities within and among countries. \\
\hline $\begin{array}{l}\text { Goal 11: Sustainable Cities and } \\
\text { Communities }\end{array}$ & To make cities inclusive, safe, resilient and sustainable. \\
\hline $\begin{array}{l}\text { Goal 12: Responsible Consumption } \\
\text { and Production }\end{array}$ & To ensure sustainable consumption and production patterns. \\
\hline Goal 13: Climate Action & To take urgent action to combat climate change and its impacts. \\
\hline Goal 14: Life Below Water & To conserve and sustainably use the oceans, seas and marine resources. \\
\hline Goal 15: Life on Land & $\begin{array}{l}\text { To sustainably manage forests, combat desertification, halt and reverse } \\
\text { land degradation, and halt biodiversity loss. }\end{array}$ \\
\hline $\begin{array}{l}\text { Goal 16: Peace, Justice and Strong } \\
\text { Institutions }\end{array}$ & To promote just, peaceful and inclusive societies. \\
\hline Goal 17: Partnerships for the Goals & To revitalize the global partnership for sustainable development. \\
\hline
\end{tabular}

As [8] mentioned, the fulfillment of these goals is closely linked to the education. It is vital to educate and prepare next generations with the foundations included in the SGDs. To do so, new learning methodologies or existing ones should be adapted to be applied to promote the sustainable development. For this reason, it is also advisable, as with the TCs, to include SGDs in the curricula of students, through the study plans; students' end-of-degree and master's projects and/or extracurricular activities.

\subsection{Project-Based Learning (PBL)}

There is a large number of different learning techniques and methodologies to motivate students and make their learning, deeper and lasting over time. Currently, lecturers use different learning techniques. These include those that, although traditional, are often used to reinforce learned knowledge such as the use of debates [10], games [11,12], to mention a few. There are other active methodologies such as project or problems based-learning in which the teaching process is focused on the student $\sin$ a constructive way, since the student is an active part of the teaching-learning process. It is also worth mentioning emergent and/or technological learning methodologies such as gamification, blended learning, flipped teaching, among others.

This paper is focused on the use of the active methodology of PBL as the way to solve real challenges from a critical and analytical perspective, fostering the generation of appropriate questions to promote the metacognition. This methodology promotes active teaching in which students are the main actors. With this methodology students solve challenging situations, raise questions, and try to answer them using their knowledge, means, resources, research, reflection in an active and collaborative way. It is not a new methodology, but it is unquestionable that in the last years it has been implemented in a generalized way in comparison with other educational trends.

Edgar Dale [13] theorized that students retain more information by what they "do" as opposed to what is "heard", "read" or "observed". Moreover, he designed the Edgar Dale's Cone of Experience in which the basis is related to "direct purposeful experience - go through a direct experience" in which 
students will remember $90 \%$ of what they do as they perform the project. Therefore, it seems that PBL is related to this "do" level in which students will retain more information based on "learning by doing".

As aforementioned, the PBL methodology is a student-centred learning strategy. Reference [14] states that this should be based on four learning objectives: (i) constructive learning: by connecting new knowledge to students' prior knowledge; (ii) collaborative learning: by working in groups to enhance learning through working together and sharing knowledge [15]; (iii) contextual learning: by applying new knowledge and skills to real-life situations; and (iv) self-directed learning: by managing and regulating the learning through planning, monitoring, and evaluating activities.

The educational models of PBL incorporate these four learning principles and have been further developed in direct response to the calls for innovation and transformation in sustainability education [16]. Therefore, this research proposes a PBL model to incorporate TCs and SDGs through a PBL methodology.

\section{DESIGN AND APPLICATION OF PBL IN SGDS LEARNING PROCESS IN THE MECHANICAL ENGINEERING DEGREE}

The proposal is focused on the integration of both transversal competences and sustainability development goals (SDGs) in the training process of the students, using a project-based learning (PBL) methodology.

The Mechanical Engineering Bachelor's Degree at the Universitat Politècnica de València is taught in four years. The bachelor's degree is organized in first three courses in which the students learn basic formation (e.g., Mathematics, Physics, Graphic design), the field of industrial engineering (e.g., Technical office, Machines and mechanisms, Fluid mechanics, Electrical machines) and the mechanical specialization (e.g., Fluid-Mechanical engineering, Machines design, Structures). The fourth year, the students choose one specialization between four possibilities. These fields are: (i) Design and Engineering of Vehicles, (ii) Design and Manufacturing of Machines, (iii) Project Engineering and (iv) Design and Calculation with Polymeric and Composite Materials [17]. Table 2 shows the European Credit Transfer and Accumulation System (ECTS) in each study phase.

Table 2. Studies in Mechanical Engineering Bachelor's Degree.

\begin{tabular}{l|c}
\hline \multicolumn{1}{c|}{ Area } & ECTS \\
\hline Basic Formation & 60 \\
\hline Field of Industrial Engineering & 60 \\
\hline Mechanical Specialization & 60 \\
\hline Specialization & 48 \\
\hline Bachelor Thesis & 12 \\
\hline \hline
\end{tabular}

The Escuela Politècnica Superior de Alcoy (EPSA) proposed an educational innovation and improvement project since 2019. It is focused on developing of strategies to implement project-based learning (PBL) in some subjects of the degree [18]. The goal is the fixing of some subjects, which will be the germ to reach the total implementation of the PBLs techniques in the future of the bachelor's degree. The PBL methodology does not only focus on reaching the general and specific competences of the degree but it will be able to measure the acquisition of the different transversal competences as well as the sustainable development goals proposed by United Nations to reach in 2030. The transversal competences are thirteen abilities, which should be reached by students according to UPV strategic plan [19]. UPV also proposed the integration of SDGs in the curricula of the students, firstly in the development of their bachelor and master thesis degree and after, integrating the SDGs in the subjects of their curricula.

\subsection{Case Study}

The proposed case study is focused on the subjects, which are related of the hydraulic and environmental engineering department. Particularly, these are fluid mechanics and hydraulic machines. Both subjects are taught in Mechanical Engineering Bachelor's Degree. Fluids mechanics is imparted in second course and the students are between 19 and 23 years old. Generally, the number of students is around 160. This subject is divided into two theoretical groups and three of practical lesson groups. The subject, called Hydraulic machines is imparted in third course. The 
students are enrolled in this subject, once they have studied the first one: fluid mechanics. The students are between 20 and 24 years old and there are 130 students approximately, divided into the same number of groups of Fluid Mechanics.

Table 3 shows the relationship between transversal competences and SDGs in the Mechanical Engineering Bachelor's Degree applied to subjects of fluid mechanics and hydraulic machines. When students take both subjects, they work all transversal competences as well as a vast number of the SDGs. Particularly, they work the SDG-6 and SDG-7 deeply, however the teachers establish the need to introduce the SDG-5, developing infrastructures, which guarantee the development of the sustainable areas, mainly cities (SDG-11). These goals can be reached using different tools and proposing different activities, on which the students work the specific competences of the subject, developing other competences. Although both subjects work the thirteen competences, the TC-3, TC5 and TC-10 are worked in detail in the PBL model, which is defined in the following section.

This research only describes one of the developed activities. When the students course these subjects (Fluid Mechanics and Hydraulic Machines), they are involved in four different activities, two of which are related to PBL methodologies and the other two are applied to practical thinking, in which students have to search information, summarize it and present it in an oral exposition about hydraulic current topic.

Table 3. Transversal competences and SDGs worked in the subjects of Fluid Mechanics and Hydraulic Machines.

\begin{tabular}{|c|c|c|c|c|c|c|c|c|c|c|c|c|c|c|c|c|c|}
\hline$S D G$ & 1 & 2 & 3 & 4 & 5 & 6 & 7 & 8 & 9 & 10 & 11 & 12 & 13 & 14 & 15 & 16 & 17 \\
\hline 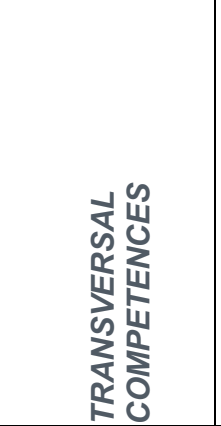 & 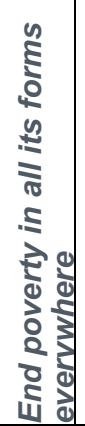 & 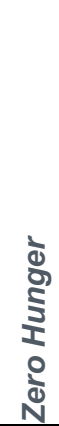 & 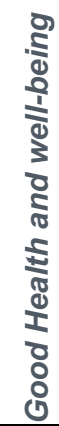 & 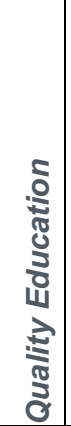 & 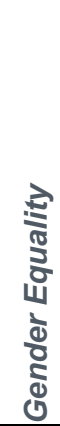 & 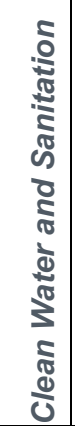 & 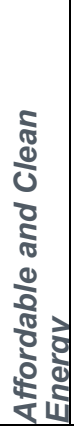 & 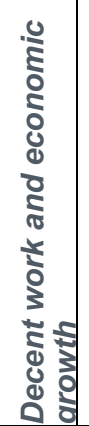 & 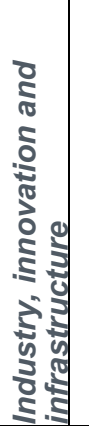 & 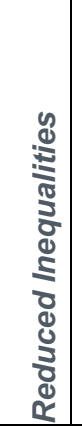 & 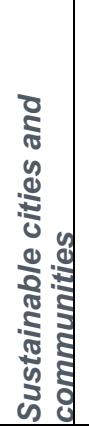 & 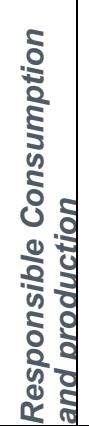 & 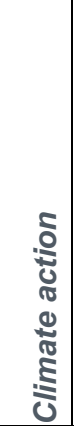 & 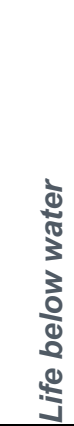 & 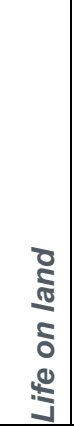 & 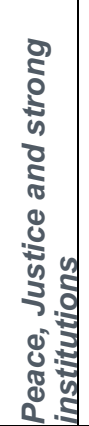 & 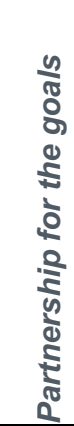 \\
\hline $\begin{array}{l}\text { 1. Comprehension } \\
\text { and integration }\end{array}$ & & & & $x$ & $x$ & $x$ & & $X$ & & $X$ & & & & & & & \\
\hline $\begin{array}{l}\text { 2. Application } \\
\text { and practical } \\
\text { thinking }\end{array}$ & $x$ & & & & & $X$ & $x$ & & $x$ & & $X$ & & & $X$ & $X$ & & \\
\hline $\begin{array}{l}\text { 3. Analysis and } \\
\text { problem solving }\end{array}$ & $X$ & $X$ & $X$ & $X$ & $X$ & $x$ & $X$ & & & & $X$ & $X$ & $X$ & & & & \\
\hline $\begin{array}{c}\text { 4.Innovation, } \\
\text { creativity and } \\
\text { entrepreneurship }\end{array}$ & & & & & & $X$ & & & $x$ & & $X$ & & & & & & \\
\hline $\begin{array}{l}\text { 5. Project and } \\
\text { design }\end{array}$ & $X$ & $X$ & & & & $x$ & $X$ & $X$ & $X$ & & & & & $X$ & $X$ & & \\
\hline $\begin{array}{l}\text { 6. Teamwork } \\
\text { and leadership } \\
\end{array}$ & $X$ & & $X$ & & $x$ & & & & & $X$ & & & & & & & \\
\hline $\begin{array}{c}\text { 7. Ethical, } \\
\text { environmental } \\
\text { and professional } \\
\text { responsibility }\end{array}$ & $x$ & $x$ & $x$ & $x$ & $x$ & $x$ & $x$ & $x$ & $x$ & $X$ & $X$ & $x$ & $x$ & $X$ & $X$ & $X$ & $x$ \\
\hline $\begin{array}{c}\text { 8. Effective } \\
\text { communication }\end{array}$ & & & & $x$ & $X$ & & & $X$ & & & & & $X$ & & & & \\
\hline $\begin{array}{l}\text { 9. Critical } \\
\text { thinking }\end{array}$ & $X$ & $X$ & $X$ & $X$ & $X$ & $x$ & $X$ & $X$ & $X$ & $X$ & $X$ & $X$ & $X$ & $X$ & $X$ & $X$ & $X$ \\
\hline $\begin{array}{l}\text { 10. Permanent } \\
\text { Learning }\end{array}$ & $X$ & $x$ & $X$ & $x$ & $x$ & $x$ & $X$ & $X$ & $X$ & $X$ & $X$ & $X$ & $X$ & $X$ & $X$ & $X$ & $X$ \\
\hline 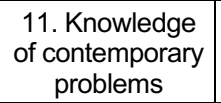 & $X$ & $x$ & & & & $x$ & & & & & $X$ & $X$ & & & & & \\
\hline 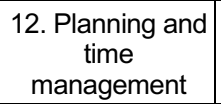 & & & & $X$ & $x$ & & & & & & & & & & & & \\
\hline $\begin{array}{l}\text { 13. Specific } \\
\text { instruments }\end{array}$ & $X$ & $X$ & $X$ & $x$ & $X$ & $x$ & $X$ & $X$ & $X$ & $X$ & $X$ & $X$ & $X$ & $X$ & $X$ & $X$ & $X$ \\
\hline
\end{tabular}




\subsection{Proposed Activity}

The PBL activity is originated in the subject Fluid Mechanics. In this case, the students have to design a water network, sizing pipes and valves. This sizing is different for each student, who has a different consumption pattern as well as different topology. The activity is developed according to PBL methodology. The students can learn the calculus methodology by short movies, which are called 'polimedia' in the Network Teaching Project of UPV [20]. These videos have a length around 5 and 10 minutes, and they show the different steps to design the diameter of a pipe, according to flow by slope criterium. Moreover, the activity is supported by a practical session in which students learn how to use the Epanet software [21]. This software is used to run a simulation in extended period, analysing the variation of the pressure and flow values in the lines. When the model is correct and it is analysed according to hydraulic conditions, students develop a short budget according to length of pipes as well as the chosen material. This network will be used by the same students in the subject Hydraulic Machines, where students introduce pump stations and reservoirs in their networks [22]. This structure of activities allows students to establish a vertical coordination between subjects and therefore, to provide students with a continuous stream in the development of the project. This project could be connected with other subjects of other departments such as structures or design of machines to give a horizontal coordination to the PBL activity.

The described activity works the following transversal competences:

1 Application practical thinking (TC-2); students have to think the way of the different pipes to supply the demand.

2 Analysis and problem solving (TC-3); students have to solve the problems of height or constrains (e.g., mountains, rivers, factories, streets, among others) to guarantee the continuity of the network.

3 Innovation, creativity and entrepreneurship (TC-4); students have to be innovators and they have to develop their creativity to propose the best route, which guarantees the demand as well as the less length, and therefore, the low budget.

4 Project design (TC-5); students have to design the network proposing materials and diameters of the different pipes.

5 Professional, environmental and ethical responsibility (TC-7); students have to be professional and work ethically considering the environmental and its impacts, guaranteeing the correct operation of the system.

6 Continuous learning (TC-11); students learn as they develop the project, watching the videos, attending practical lessons as well as asking to professors to solve doubts.

7 Planning and time management (TC-12); students have to organize and manage the time to present the project before of the proposed deadline. They work on this project during 5 weeks, and they can organize the work development according to their preferences.

8 Instrumental specific (TC-13); students use different software such as Epanet, AutoCad and Excel to solve the project, and therefore, they acquire abilities to apply the Fluid Mechanics concepts to real case studies.

The project also allows students to work on different SDGs. This activity involves the following SDGs:

1 End poverty in all its forms everywhere (SDG-1); students are able to develop water systems, which can be designed and implemented in developing countries. The development of water systems enables to reduce the poverty of these areas.

2 Quality Education (SDG-4); the students develop this work at a university and therefore, they are accessing to an education with quality.

3 Gender Equality (SDG-5); all students have to design and develop the project without distinctions, therefore the activity shows both sexes are able to solve the water supply issues properly.

4 Clean Water and Sanitation (SDG-6); students design a water network to satisfy the demand efficiently.

5 Reduced Inequalities (SDG-10); the water access to all the population guarantees the reduction of the inequalities and it is internalized by students when they develop the activity as their project allows people to have water in their house. 
6 Sustainable cities and communities (SDG-11); students design their water networks considering the efficiency and sustainable principles to reach a sustainable development of the world

The activity allows students to work 8 TCs and 6 SDGs together in the same activity. Moreover, the development of the activity shows the satisfaction of the students, who answered a survey when the activity finished. $74 \%$ of the students (111 of 123 students answered the survey) preferred the use of a PBL methodology than traditional ones.

\section{CONCLUSIONS}

From a professional viewpoint, it is of utmost importance that university graduates have been trained in TCs as those capacities, abilities and aptitudes that make them effective at the professional level. However, in the current paradigm it is also vital the protection of the planet and the guarantee of a sustainable development for the humanity prosperity. In this sense, the Union Nations defined 17 SDGs addressed to build economic growth and focused on a range of social needs including education, health, social protection, and job opportunities, while tackling climate change and environmental protection [9].

Therefore, new generations should be trained from a professional viewpoint through the TCs to be able to give a response to the market demands but also from a sustainable viewpoint to guarantee the long-term protection of the planet and society.

To do so, it is worth mentioning that there are several learning methodologies addressed to the promote deep learning, however it seems that active methodologies, such as PBL, are the most appropriate to make students remember the greatest amount of knowledge, due to the fact that PBL is based on a direct experience by the development of the project.

For this reason, this paper proposes a learning approach based on PBL to achieve and enhance students' knowledge about SDGs in parallel with the TCs development. In addition, an illustrative example of a PBL model applied to some of the 17 SGDs is defined in the mechanical engineering degree that can be used as the basis for other teachers in other subjects and/or degrees.

\section{ACKNOWLEDGEMENTS}

This article has been supported by Universitat Politècnica de València, particularly by the Vicerectorate for Digital Resources and Documentation (Vicerrectorado de Recursos Digitales y Documentación) and Vice-Rectorate for Studies, Quality and Accreditation (Vicerrectorado de Estudios, Calidad y Acreditación) under the Call for Learning + Teaching (Convocatoria A+D2019: Aprendizaje + Docencia. Proyectos de Innovación y Mejora Educativa) and Project Code: A157. The authors would like to acknowledge the support of the Institute of Educational Sciences (Instituto de Ciencias de la Educación), the Evaluation and Monitoring Commission for Educational Innovation and Improvement Projects (Comisión de Evaluación y Seguimiento de Proyectos de Innovación y Mejora Educativa (CESPIME) and Escuela Politécnica Superior de Alcoy.

\section{REFERENCES}

[1] UPV, "Conoce el Proyecto de las Competencias Transversales UPV. Objetivos y Alcance del Proyecto", 2020. Retrieved from http://www.upv.es/contenidos/COMPTRAN/info/955689normalc.html

[2] J. Balcar, L. Janickova, L. Filipova, "What general competencies are required from the Czech labour force?", Prague Econ. Pap. Vol. 2, pp. 250-265, 2014.

[3] P. Gómez-Gasquet, M.J. Verdecho, R. Rodriguez-Rodriguez, J.J. Alfaro-Saiz, "Formative assessment framework proposal for transversal competencies: Application to analysis and problem-solving competence", J Ind Eng Manag, Vol. 11, No. 334, 2018.

[4] M.J. Sá, S. Serpa, S, "Transversal competences: Their importance and learning processes by higher education students", Educ Sci, Vol. 8, No. 3, 2018

[5] UPV, "Conoce el Proyecto de las Competencias Transversales UPV. Incorporación de las Competencias Transversales UPV", 2020. Retrieved from http://www.upv.es/contenidos/COMPTRAN/info/955693normalc.html 
[6] UPV, "Conoce el Proyecto de las Competencias Transversales UPV. Las Competencias Transversales UPV", 2020. Retrieved from http://www.upv.es/contenidos/COMPTRAN/info/955709normalc.html

[7] UPV, "Conoce el Proyecto de las Competencias Transversales UPV. Evaluación de las Competencias", 2020. Retrieved from http://www.upv.es/contenidos/COMPTRAN/info/962048normalc.html

[8] M. Pérez-Sánchez, M. Díaz-Madroñero Boluda, J. Mula, R. Sanchis, "The Sustainable Development Goals (SDGs) Applied to Higher Education. A Project Based Learning Proposal Integrated with the SDGs in Bachelor Degrees at the Campus Alcoy (UPV)", EDULEARN Proceedings, pp. 3997 - 4005, 2020.

[9] United Unions, "Sustainable Development Goals", 2020. Retrieved from https://www.un.org/sustainabledevelopment/

[10] R. Sanchis, R. Poler, R. "Initial Debate as an Innovative Method to Introduce a New Subject", INTED proceedings, pp. 3966 - 3973, 2019.

[11] R. Sanchis, B. Andres, R. Poler, "Traditional Games to Reinforce the Knowledge Learned in an Engineering Master Degree", INTED Proceedings, pp. 5905 - 5911, 2017.

[12] B. Andres, R. Sanchis, R. Poler, "Quiz Game Applications to review the concepts learnt in class: An application at the University Context", INTED Proceedings, pp. 5654-5662 , 2015.

[13] E. Dale. Audio-visual methods in teaching. New York: The Dryden Press, 1946.

[14] D. Dolmans, H. Schmidt, "The problem-based learning process", in Lessons from problembased learning (H. Van Berkel, A. Scherpbier, H. Hillen, C. vander Vleuten eds.), Oxford: Oxford University Press, 2010.

[15] R. Sanchis, M.R. Sanchis-Gisbert, R. Poler, "Conceptualisation of the three-dimensional matrix of collaborative knowledge barriers", Sustainability, Vol. 12, No. 3, 2020.

[16] R. Cörvers, A. Wiek, J. de Kraker, D.J. Lang, P. Martens, "Problem-based and project-based learning for sustainable development" in Sustainability Science, pp. 349-358, Dordrecht: Springer, 2016.

[17] R. Balart, N. Montanes, L. Quiles-Carrillo, S. Jordá-Gisbert, H.C. Sanchis-Gomis, Sanchis, R., "Model Design and Calculation with Polymeric and Composite Materials through Project-Based Learning", EDULEARN Proceedings, pp. 3979 - 3986, 2020.

[18] R. Sanchis, J. Mula, B. Cantó Colomina, D. Garcia-Sanoguera, J.I. Torregrosa López, "Diseño de la Incorporación del Aprendizaje Basado en Proyectos en las Titulaciones de Grado del Campus de Alcoy de la Universitat Politècnica de València", VI Congreso Nacional de Innovación Educativa y Docencia en Red, Editorial Universitat Politècnica de València, 2020.

[19] UPV, "Plan estratégico 2015-2020", 2020. Retrieved from https://www.upv.es/noticiasupv/documentos/plan_estrategico_upv2020.pdf

[20] UPV, "Docencia en Red", 2020. Retrieved from https://www.upv.es/contenidos/DOCENRED/index-en.html

[21] L.A. Rossman. EPANET 2 Users Manual. U.S. Environmental Protection Agency, Washington, D.C., EPA/600/R-00/057, 2000.

[22] M. Pérez-Sánchez, P.A. López-Jiménez, "Continuous Project-Based Learning in Fluid Mechanics and Hydraulic Engineering Subjects for Different Degrees", Fluids, Vol. 5, No. 2, 2020. 